Vol. 16, $n^{\circ} 1 \mid 2012$

Varia

\title{
Kalifa (Dominique), Crime et Culture au XIXe siècle
}

Paris, Éditions Perrin, 2005, 331 p., ISBN 2262020124.

Peter Becker

\section{(2) OpenEdition}

\section{Journals}

Electronic version

URL: https://journals.openedition.org/chs/1332

DOI: $10.4000 /$ chs. 1332

ISSN: 1663-4837

\section{Publisher}

Librairie Droz

\section{Printed version}

Date of publication: 1 May 2012

Number of pages: 123-125

ISBN: 978-2-600-01594-3

ISSN: 1422-0857

\section{Electronic reference}

Peter Becker, "Kalifa (Dominique), Crime et Culture au XIXe siècle", Crime, Histoire \& Sociétés / Crime, History \& Societies [Online], Vol. 16, $n^{\circ} 1$ | 2012, Online since 12 March 2013, connection on 23 March 2022. URL: http://journals.openedition.org/chs/1332 ; DOI: https://doi.org/10.4000/chs.1332

This text was automatically generated on 23 March 2022.

(c) Droz 


\section{Kalifa (Dominique), Crime et Culture au XIX siècle}

Paris, Éditions Perrin, 2005, 331 p., ISBN 2262020124.

\section{Peter Becker}

\section{REFERENCES}

Kalifa (Dominique), Crime et Culture au XIX ${ }^{e}$ siècle. Paris, Éditions Perrin, 2005, 331 p., ISBN 2262020124.

1 Dominique Kalifa, the renowned expert on crime in its social, cultural, and political context, casts a fresh analytical glance at the popular obsession with crime in nineteenth- and early twentieth-century France. Written in elegant and at times extremely entertaining prose, Kalifa takes the reader into the dark streets of Paris and inside the prisons to an exotic social milieu. He also allows the reader to peer over the shoulders of pen-wielding police practitioners, as well as judges in the courtrooms, criminal anthropologists in their laboratories, and journalists who were the figureheads of the modern media.

2 The themes developed in this fine book have been central to the concerns of the author throughout much of his intellectual career, and for this reason, most of the chapters have already been published elsewhere in earlier versions. They nevertheless hold well together and provide a series of well integrated case studies. The book offers new insights into the cultural and political history of the nineteenth century, a time which saw the appearance of the epistemological tools, representational strategies, and political instruments which still shape our approach to crime. The author strongly insists on this point and takes this as his starting point, from where he develops a systematic reflection on the relations between crime and culture in the fields of cultural production, social integration and exclusion, and, finally, individual and collective attempts to come to terms with events beyond comprehension (10-12). 
... le crime est toujours un événement incompréhensible. Un fait opaque, dont les mobiles ou les circonstances ne sont jamais transparents, une sorte de point aveugle, et une histoire souvent indicible (11f.).

3 The book is divided into three parts: notorious criminals, mass-culture, and delinquency and insecurity. From these different perspectives the author analyses the various ways in which investigations, narratives, and political programmes threw light on potential blind spots of crime. All these themes have been explored, to a greater or lesser extent, by other scholars. Yet Kalifa's contribution is more than just adding to an existing field of research. He offers new insights into changing forms of public consciousness and collective sensitivities through a subtle analysis of a broad variety of texts in their political, cultural, and social contexts.

4 The first part is an excellent tour de force through figures of crime during the nineteenth and early twentieth centuries. These figures carry a wider significance in this book as they refer both to the material space where crimes took place, and to the persona of notorious criminals, as well as to authors of crime fiction. This comprehensive understanding of the criminal as a character enables the author to combine an assessment of the sites of crime in Paris and their relocation following the restructuring of Paris under Haussmann with the presentation of a new genre of crime fiction, followed by a thorough analysis of criminal investigation in Les Misérables, and a comment on the Fantômas-series.

5 I would like to highlight especially the chapter on the autobiographies of police practitioners in nineteenth-century France. This research has not been published before. It is a highly innovative piece of research and presents the steady stream of publications from the pen of police experts as highly relevant for a history of policing and criminology. Kalifa considers these publications as a specific genre, which he approaches with an interest in the authors, their subjectivity, the self-representation of their professional role, and their prevalence in the book market and the media :

C'est comme tels qu'on voudrait les prendre ici, non pour ce qu'ils pourraient éventuellement nous dire sur le monde, mais pour ce qu'ils nous disent effectivement sur eux-mêmes (68).

6 His reading of the autobiographies of police practitioners should inspire historians of crime and policing to more systematically scour libraries for these publications in other European and American cities. In my own research, I came across several of them in Germany and I would expect a similar result elsewhere. These texts and the paratexts around them provide fascinating insights into the self-projection of these authors, into the expectations of the targeted audiences, and into the ways in which policing is linked to the State, to technology, and to society. For this reason, a comparative perspective could be highly rewarding to pinpoint commonalities and differences regarding political, institutional, and media culture as well as exchanges between authors with different national backgrounds.

7 The second part of the book carries the argument further, opening with a brilliant analysis of representational strategies of crime in the late nineteenth-century massmedia culture. The first chapter looks at short press reports on everyday crime as well as at crime novels. The two genres are strikingly different but Kalifa argues that both played an important role in telling the 'truth' about the reality of crime and shaped the way in which people engaged with the world around them (134). He characterizes the faits divers as texts which worked mainly through accumulation and repetition; their 
selection was as much based on information as on entertainment. He uncovers archival evidence from journalists to critically reflect on the veracity of the faits divers. Yet Kalifa is not interested in denouncing the press reports as artefacts. Instead he argues that their impact was based on the willingness of the readers to engage with them and to align their own experiences with them (141f.). I was also impressed by the second part of the chapter, where he continues his reflections on the mode of criminal investigation and links the changes in policing to changes in political culture and political subjectivity :

L'enquête se donne en effet comme le privilège de l'homme démocratique, cet individu doué de raison, à la fois lecteur et électeur, mais aussi enquêteur potentiel (153).

8 I have chosen these two chapters to offer an impression of the fruitfulness of Kalifa's cultural studies approach to crime as political, social, and media reality. Due to the strong focus on texts and their institutional contexts, he pays particular attention to the role of the new mass-media and its institutions. His analysis looks at the circulation of texts across the borders of institutionally defined subsystems and thereby avoids any false impression of division of labour: Police practitioners investigate, but their writings are not only for readers of their official reports, but for a larger audience. Journalists write for a mass-audience, but they also increasingly become involved in investigative activities. This circulation opens challenging questions both about the impact of the institutional settings on the production and circulation of texts, and about the role of the media in selecting and promoting certain themes. The third part of the book takes up these issues with a fresh look at the political and public debate about the crisis of crime-fighting and social defence.

The book is best characterized as an inspiring and thought-provoking reading for scholars working on the history of crime, policing, and the mass-media. It offers many insights, and although it is written in an easily accessible style, the reader will have to pause every now and then - not out of exhaustion but for the full appreciation of the many stimulating and eye opening points, which are to be found in this book.

\section{AUTHORS}

\section{PETER BECKER}

peter.becker@mac.com 